\title{
Archaeological Testing (Phase II) of Prehistoric Site 41BX785 for the West Salado Creek Outfall Project, Bexar County, Texas
}

Ronald W. Burkett

Follow this and additional works at: https://scholarworks.sfasu.edu/ita

Part of the American Material Culture Commons, Archaeological Anthropology Commons, Environmental Studies Commons, Other American Studies Commons, Other Arts and Humanities Commons, Other History of Art, Architecture, and Archaeology Commons, and the United States History Commons

Tell us how this article helped you.

This Article is brought to you for free and open access by the Center for Regional Heritage Research at SFA ScholarWorks. It has been accepted for inclusion in Index of Texas Archaeology: Open Access Gray Literature from the Lone Star State by an authorized editor of SFA ScholarWorks. For more information, please contact cdsscholarworks@sfasu.edu. 


\section{Archaeological Testing (Phase II) of Prehistoric Site 41BX785 for the West Salado Creek Outfall Project, Bexar County, Texas}

\section{Creative Commons License}

\section{(c) (1) \&}

This work is licensed under a Creative Commons Attribution-NonCommercial 4.0 International License 


\section{ARCHAEOLOGICAL TESTING (PHASE II) OF PREHISTORIC SITE 41 BX 785 FOR THE WEST SALADO CREEK OUTFALL PROJECT, BEXAR COUNTY, TEXAS}

RONALD W. BURKETT

CENTER FOR ARCHAEOLOGICAL RESEARCH

THE UNIVERSITY OF TEXAS AT SAN ANTONIO ARCHAEOLOGICAL SURVEY REPORT, NO. 182

1989 





\section{ARCHAEOLOGICAL TESTING (PHASE II) OF PREHISTORIC SITE 41 BX 785 FOR THE WEST SALADO CREEK OUTFALL PROJECT, BEXAR COUNTY, TEXAS}

Ronald W, Burkett

Texas Antiquities Committee Permit No. 737

Center for Archaeological Research The University of Texas at San Antonio(

Archaeological Survey Report, No. 182 
The following information is provided in accordance with the General Rules of Practice and Procedure, Chapter 41.11 (Investigative Reports), Texas Antiquities Committee:

1. Type of investigation: limited subsurface testing;

2. Project name: West Salado Creek Outfall;

3. County: Bexar;

4. Principal investigator: Jack D. Eaton;

5. Name and location of sponsoring agency: Seligmann and Pyle Consulting Engineers, Inc., 3918 Naco-Perrin, San Antonio, Texas, 78217;

6. Texas Antiquities Committee Permit No. 737;

7. Published by the Center for Archaeological Research, The University of Texas at San Antonio, 78285-0658, 1989.

A list of publications by the Center for Archaeological Research can be obtained by sending $\$ 1.00$ to the Center for Archaeological Research, The University of Texas at San Antonio, San Antonio, Texas, 78285-0658. 


\begin{abstract}
During October and November 1988, subsurface testing (Phase II) was conducted at prehistoric site $41 \mathrm{BX} 785$, found in the West Salado Creek Outfall pipeline easement during a pedestrian survey (Phase I) of the project area. The Phase II limited testing determined that the subsurface portion of the prehistoric site is essentially intact, and at least two stratified occupation levels were identified. Although the tests did not produce diagnostic (datable) cultural materials, there is a notable amount of stone tool debitage in the central area, some unidentified biface fragments and burned rock which probably represents displaced hearth stones. We believe the site to be potentially eligible for consideration as a State Archeological Landmark and for nomination to the National Register of Historic Places. Because the site lies within the pipeline easement and will be impacted by the installation of the pipeline, and since it is a potentially significant cultural resource, we recommend that the site be considered for mitigation.
\end{abstract}


TABLE OF CONTENTS

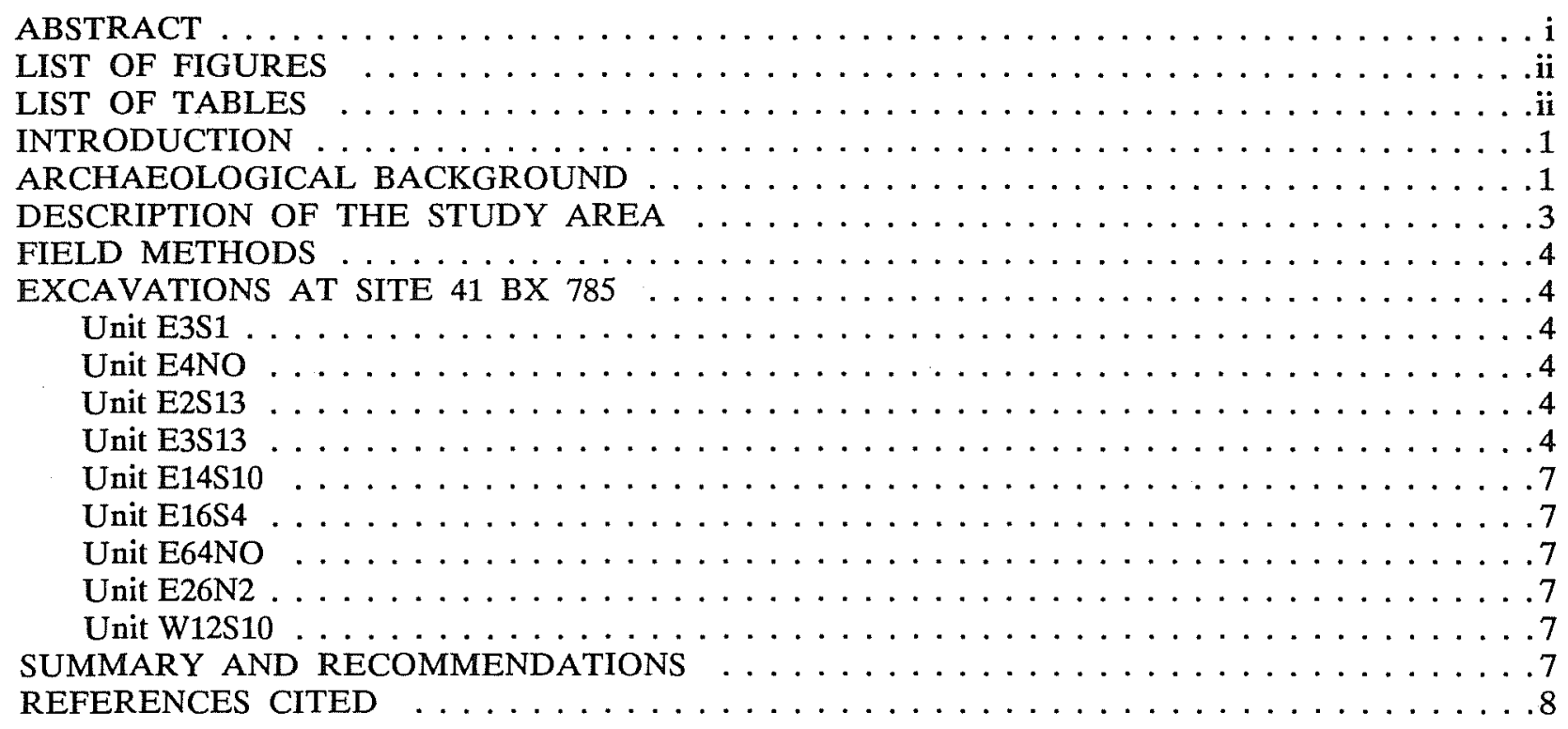

\section{LIST OF FIGURES}

1. Location of the West Salado Creek Outfall Survey Area and Archaeological Site 41 BX $785 \quad \ldots \quad \ldots 2$

2. Site 41 BX 785 Plan . . . . . . . . . . . . . . . . . . . . . . . . . . .

3. Unit/Level Comparisons of Lithic Debitage, Burned Rock Scatters, and Hearth Features from the

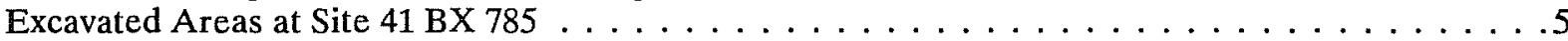

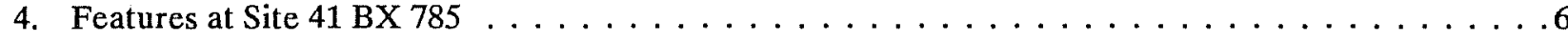

\section{LIST OF TABLES}

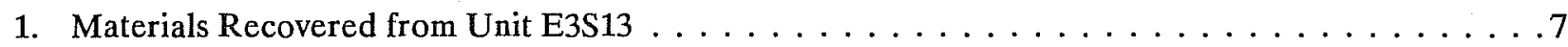




\section{INTRODUCTION}

During August 1988, a pedestrian survey was conducted within the West Salado Creek Outfall pipeline easement in southeast San Antonio, Bexar County, Texas (Burkett and Huebner 1989). As a result of that survey, one prehistoric site (41 BX 785) was recorded (Fig. 1). Surface examination and limited subsurface testing indicated buried cultural resources but of undetermined significance. Therefore, it was recommended that further testing would be needed for assessment of the potential significance of the site.

During the last week of October and the first week in November 1988, personnel from the Center for Archaeological Research (CAR), The University of Texas at San Antonio (UTSA), spent six days in the subsurface testing of that portion of $41 \mathrm{BX} 785$ transected by the 50-foot-wide West Salado Creek Outfall pipeline easement (Fig. 2). The work was conducted under contract between Seligmann and Pyle Consulting Engineers, Inc., and the CAR-UTSA. The purpose of the testing was to determine the potential of the site to be designated as a State Archeological Landmark and for potential eligibility to be nominated to the National Register of Historic Places. This site could be particularly important because of the paucity of undisturbed ground along Salado Creek and south of the Balcones Escarpment.

The investigation was carried out by CAR-UTSA staff members, Ronald W. Burkett (project director), Maureen Brown, and Clinton McKenzie with the assistance of UTSA students John Harris, Nora De La O, Debbie Ellis, and Duke Smith. The project was conducted under Texas Antiquities Committee Permit No. 737. All work was completed under the general direction of Jack D. Eaton, CAR acting director. All field notes, photographs, and other information pertinent to this project are curated at the CAR-UTSA.

\section{ARCHAEOLOGICAL BACKGROUND}

Human occupation in the central Texas area extends back at least 11,000 years (Hester 1980:131). Archaeological evidence of this occupation is organized into several generally accepted, broadly defined, cultural periods. A brief summary of these major periods or sequences (Turner and Hester 1985) follows.

Paleo-Indian, 9200 B.C. -6000 B.C.: Materially, the Paleo-Indian period is characterized by lanceolate, fluted points like Clovis and Folsom during the earlier part of the period and later by similar but unfluted points like Angostura, Scottsbluff, and Golondrina. It is this period that is associated with the hunting of large, now extinct, animals.

Early Archaic, 6000 B.C.- 2500 B.C.: Sites attributable to the Early Archaic period can be generally identified when point types such as Nolan, Bell, Andice, Martindale, Uvalde, Gower, Hoxie, and Wells are included in the artifact collection. All of these points have well-defined stems. Hunting was still a major occupation, as it continued to be into historic times, but more and more time was dedicated to the gathering and processing of vegetal matter.

Middle Archaic, 2500 B.C.-1000 B.C.: Point types within the Middle Archaic period include Pedernales, Langtry, Morhiss, Marshall, Kinney, and Tortugas. It was during this period that burned rock middens became common in the Edwards Plateau area. Also during this period, populations seemed to increase, and sites became more abundant.

Late Archaic, 1000 B.C.-300 B.C.: Montell, Castroville, Shumla, and Marcos points are indicative of the Late Archaic period. These points are all relatively large and deeply notched at the base or corners. Bison became an important food source during this period. Other major changes in food collection are signified by a decrease in the use of burned rock middens and the proliferation of specialized tool types, indicating a more diverse range of gathering and processing activities (Prewitt 1981:74).

Transitional Archaic, 300 B.C.-A.D. 700: The Transitional Archaic is recognized by smaller projectile points, including Ensor, Darl, Frio, Ellis, Edgewood, Fairland, and Figuero. Lifeways during this period seem to be a continuation of the Late Archaic.

Late Prehistoric, A.D. 700-A.D. 1600: The Late Prehistoric period is characterized by the introduction of the bow and arrow, and projectile points are very small and light. Common types include Perdiz, Fresno, Alba, Edwards, Scallorn, and Zavala. The manufacture of pottery occurs, and sherds are frequently found in sites occupied late in this period.

This rather cursory overview is presented from the standpoint of diagnostic projectile points. It is presented in this manner because the testing slated for this phase of the project was done primarily to define the cultural affiliation of site $41 \mathrm{BX} 785$.

Since 1974, at least seven survey reports (Hester 1974; Fox 1977; Brown et al. 977; Fox, McGraw, and Valdez 1978; McGraw and Valdez 1978; Gibson, Jones, and Knepper 1982; Snavely, Greco, and Fox 1984) have been published on sites within the Salado Creek watershed. These surveys have been conducted from the Panther Springs Creek area along the Balcones Escarpment in north Bexar County to the Salado Creek and San Antonio River confluence in south Bexar County. Several surface sites, usually in a 
This page has been

redacted because it

contains restricted

information. 
This page has been

redacted because it

contains restricted

information. 


\section{FIELD METHODS}

As a result of the Phase I survey, site $41 \mathrm{BX} 785$ was identified in this segment of the West Salado Creek Outfall project right-of-way (Burkett and Huebner 1989). The purpose of this second phase of the project was to test the site and make a general assessment of its potential importance, to attempt to determine the intensity of the occupation, the period or periods in which the occupation occurred, and what took place during the occupation.

A datum point was designated, horizontal and vertical control was established, and a grid system was laid out. A total of 10 areas was to be dug in one-cubic-meter test pits. All material was to be taken out at arbitrarily controlled levels and screened through 1/4-inch hardware cloth.

Enough chert debitage was recovered from the first two test pits to indicate that the occupation was more than casual. Thereafter, the majority of the field time was used in an effort to find diagnostic artifacts. In support of this effort, six $1-\mathrm{m}^{2}$ test pits were dug in a 16- $\mathrm{x} 13-\mathrm{m}$ area, and another three half-meter units were dug to establish site parameters (Fig. 2).

\section{EXCAVATIONS AT SITE 41 BX 785}

Site $41 \mathrm{BX} 785$ is located on the west side of Salado Creek and $900 \mathrm{~m}$ north of Military Drive (Loop 13). UTM coordinates for the site are 56704850 . The site is on a low stream terrace approximately $70 \mathrm{~m}$ southwest of the modern Salado Creek channel, but within the current floodplain. The elevation for the site is 558.66 feet to 560.53 feet above msl.

Subsurface testing was confined to a $17 \times 100 \mathrm{~m}$ length of pipeline easement, therefore, the total dimensions for the site are unknown at this time. Approximately $50 \mathrm{~m}$ of this easement contains intact cultural remains. Testing indicated that the site occupies some $208 \mathrm{~m}^{2}$ within and just outside of the easement. However, the site may extend to the south, between the easement and Villa Vista Drive. This area was not tested but is known to be disturbed by urban development. The site may also extend to the north toward the creek.

As indicated in the "Field Methods" section of this report, six $1-\mathrm{m}^{2}$ units and three half-meter units were excavated. Figure 3 offers a comparison of the lithic debitage, burned rock scatters, and hearth features encountered from the six $1-\mathrm{m}^{2}$ units. Each unit is individually discussed as follows.

\section{Unit E3S1}

As the test pit was opened, chert debitage began to appear immediately and increased in density to a depth of $25 \mathrm{~cm}$. At this level there was one layer of golf ball-sized burned limestone fragments. Soil color was dark gray brown, and no change was noted to this depth. The limestone fragments were removed, and Level 1 was established at $25 \mathrm{~cm}$. A total of 116 chert flakes was recovered from Level 1. Rabdotus shells and freshwater mollusk shell fragments were present throughout Level 1 but not in any recognizable concentration. Level 2 was from $26 \mathrm{~cm}$ to $50 \mathrm{~cm}$. By $50 \mathrm{~cm}$ the soil had become a lighter brown, but no definable horizon could be recognized. A total of 17 chert flakes was recovered from Level 2. No burned limestone fragments were noted in Level 2, and there were fewer Rabdotus shells. The south half of the test pit was excavated from $51 \mathrm{~cm}$ to $75 \mathrm{~cm}$, comprising Level 3. Nine chert flakes were recovered from Level 3 , and no burned limestone or Rabdotus shells were noted. The soil continued to lighten in color.

\section{Unit E4NO}

Unit E4NO produced results very similar to Unit E3S1 except that a biface fragment was recovered from Level 2.

\section{Unit E2S13}

Unit E2S13 was excavated and bagged at $25-\mathrm{cm}$ increments. Recovered from the first $25 \mathrm{~cm}$ were 29 chert flakes. By $40 \mathrm{~cm}$, the soil was noticeably lighter. Between 45 and $50 \mathrm{~cm}$, a few burned limestone fragments and an increase in Rabdotus shells were noted. A total of 141 chert flakes was recovered between 45 and $50 \mathrm{~cm}$. At $86 \mathrm{~cm}$, a possible hearth feature was identified. Seven, apparently fire reddened, sandstone rocks were laid out in an arc, the base of which was uniformly at $90 \mathrm{~cm}$ (Fig. 4,a). A burned chert fragment was found in association with this feature. This fragment appears to be the distal portion of a biface point. A total of 26 chert flakes was found between 76 and $100 \mathrm{~cm}$.

\section{Unit E3S13}

Unit E3S13 was excavated in $10-\mathrm{cm}$ levels to provide better control for the adjacent unit (E2S13). See Table 1 for a list of the materials recovered from this unit. 


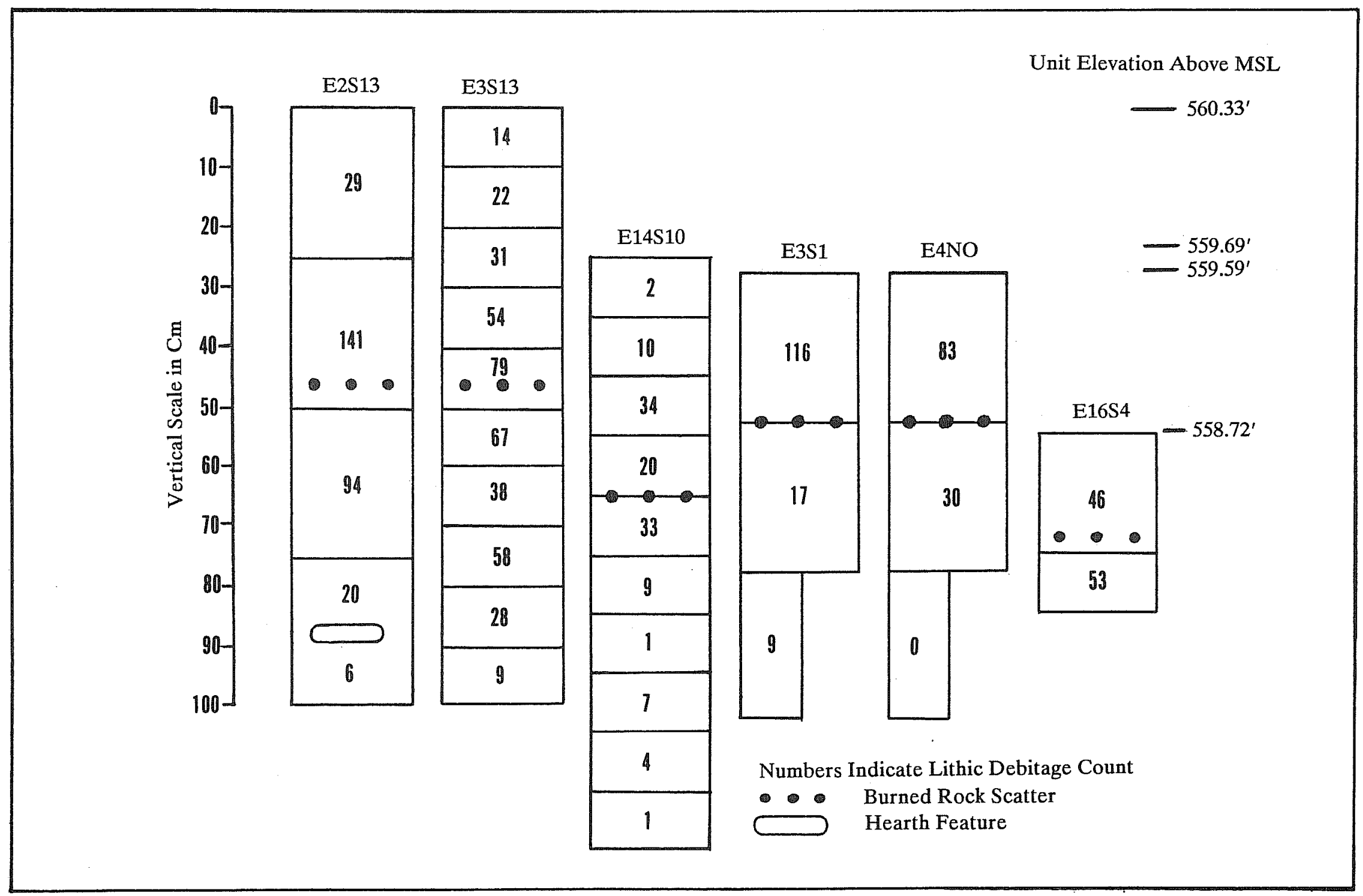

Unit Elevation Above MSL

$-560.33^{\prime}$

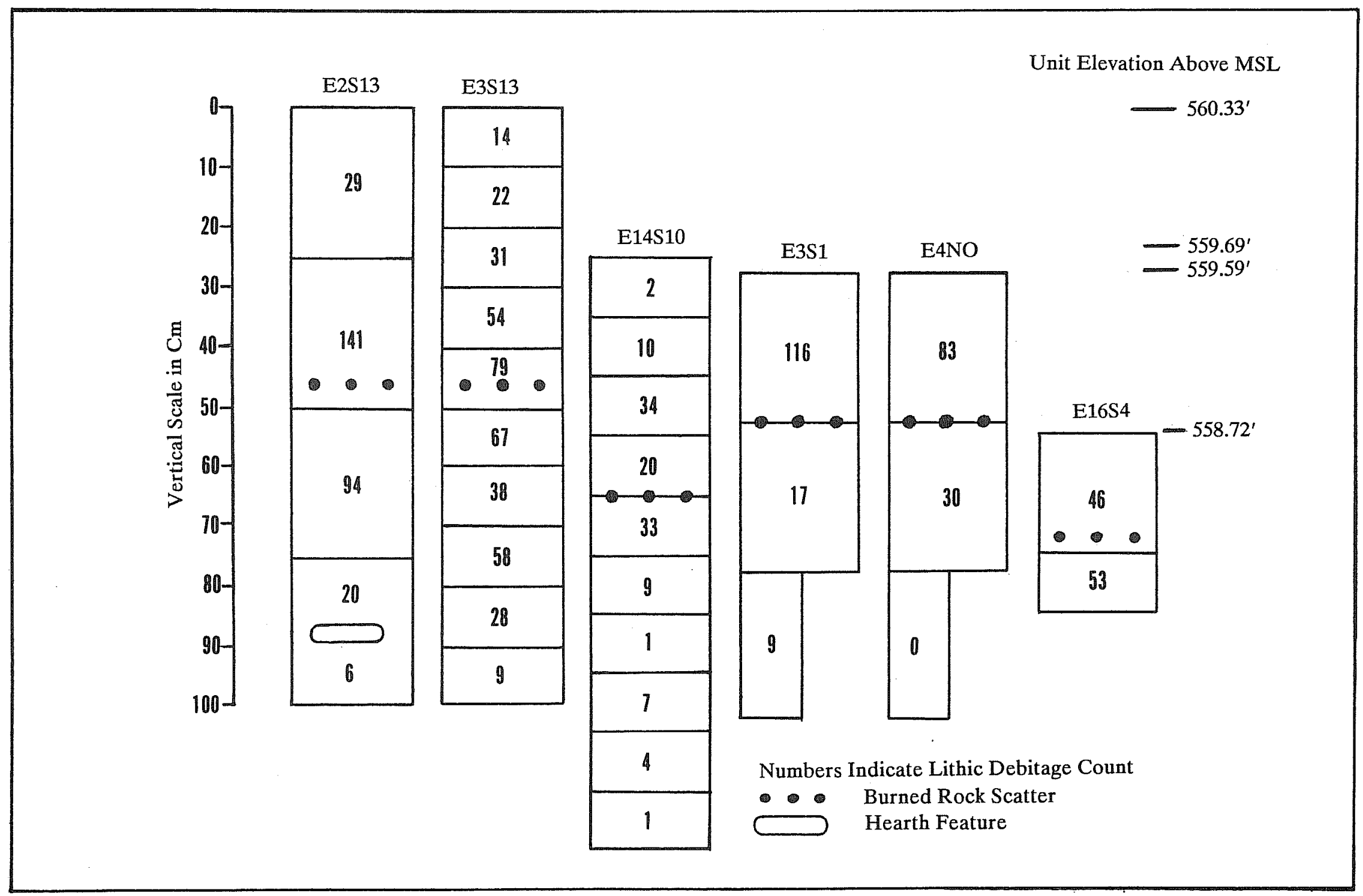

Figure 3. Unit/Level Comparisons of Lithic Debitage, Burned Rock Scatters, and Hearth Features from the Excavated Areas at Site 41 BX 785. 


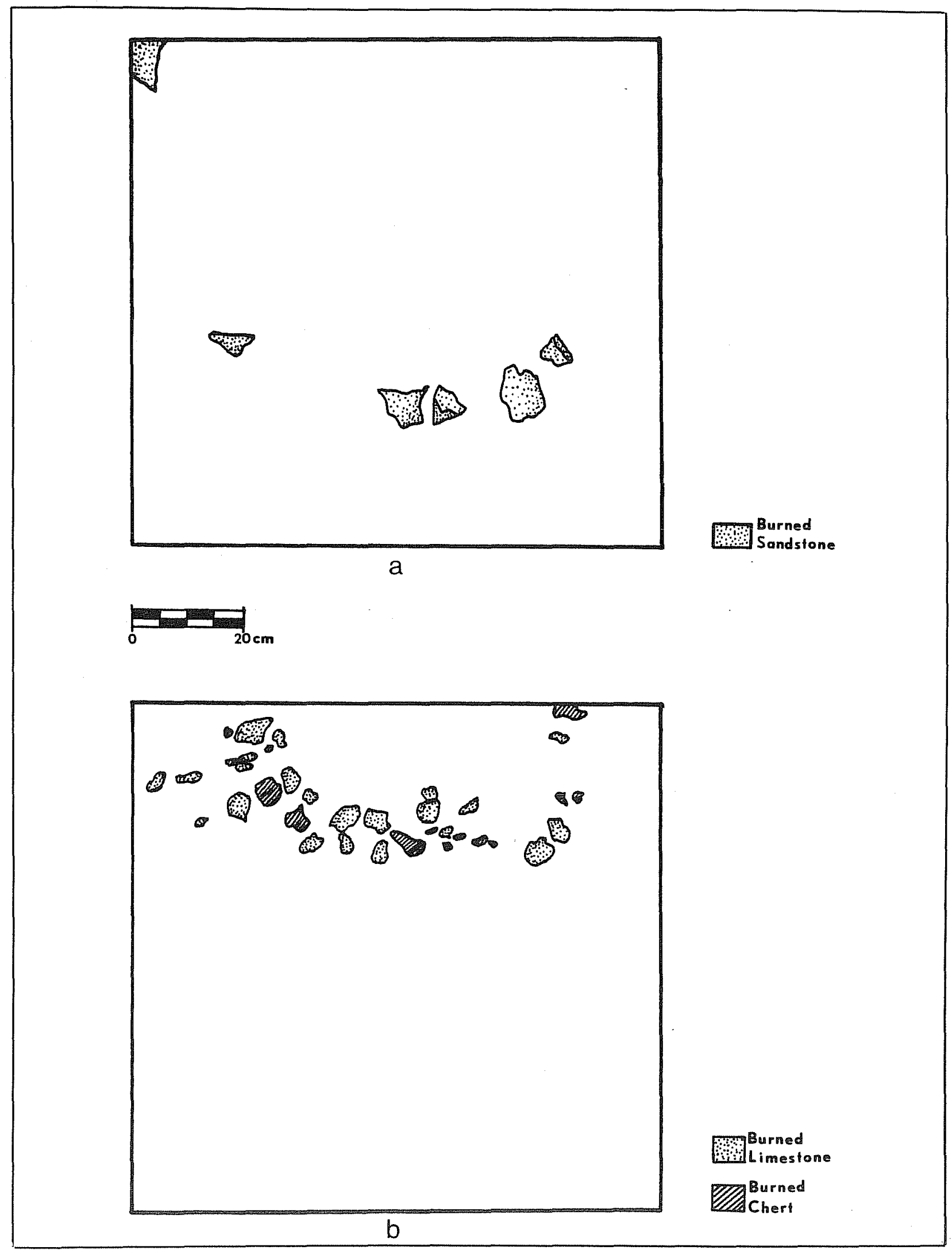

Figure 4. Features at Site 41 BX 785. a, possible hearth in E2S13 at $90 \mathrm{~cm}$ below the surface; b, burned rock and chert scatter in E16S4 at $17 \mathrm{~cm}$ below the surface. 
TABLE 1. MATERIALS RECOVERED

FROM UNIT E3S13

\begin{tabular}{ll}
\hline Depth & Materials Recovered \\
\hline $0-10 \mathrm{~cm}$ & 14 chert flakes \\
$11-20 \mathrm{~cm}$ & 22 chert flakes \\
$21-30 \mathrm{~cm}$ & 31 chert flakes \\
$31-40 \mathrm{~cm}$ & 54 chert flakes \\
$41-50 \mathrm{~cm}$ & 72 chert flakes, including 2 biface fragments. Between 46 \\
& and 50 cm was a disproportionate number of chert \\
& Ilakes and Rabdotus shells. A sample of this soil was \\
& collected. \\
$51-60 \mathrm{~cm}$ & 67 chert flakes \\
$61-70 \mathrm{~cm}$ & 38 chert flakes \\
$71-80 \mathrm{~cm}$ & 58 chert flakes, including 1 biface fragment \\
$81-90 \mathrm{~cm}$ & 28 chert flakes \\
$91-100 \mathrm{~cm}$ & 9 chert flakes \\
\hline
\end{tabular}

\section{Unit E14S10}

Unit E14S10 was excavated in 10-cm levels. A total of 121 chert flakes was recovered; the results were similar to the E3S13 unit if the levels are adjusted to take into account the $25 \mathrm{~cm}$ difference in elevation.

\section{Unit E16S4}

Burned limestone fragments were found at $17 \mathrm{~cm}$ below the surface in Unit E16S4 (Fig. 4,b). A total of 46 chert flakes was recovered between the surface and $20 \mathrm{~cm}$, and 53 chert flakes were recovered between 21 and $30 \mathrm{~cm}$.

\section{Unit E64N0}

Unit E64NO was excavated as a half-meter test unit. No debitage was recovered to a depth of $50 \mathrm{~cm}$.

\section{Unit E26N2}

Unit E26N2 was excavated as a half-meter test unit. One biface fragment was recovered at $10 \mathrm{~cm}$. One bicycle handlebar grip was recovered at $25 \mathrm{~cm}$. The unit was excavated to a depth of $50 \mathrm{~cm}$. Evidently this is in a disturbed zone with buried modern trash.

\section{Unit W12S10}

Unit W12S10 was excavated as a half-meter test unit. A few chert flakes were recovered to a depth of $50 \mathrm{~cm}$, but no burned limestone fragments were noted.

\section{SUMMARY AND RECOMMENDATIONS}

Testing at $41 \mathrm{BX} 785$ has demonstrated that at least part of the site has intact buried components and at least two occupation levels. However, no datable diagnostic artifacts were recovered, therefore the cultural/chronological placement of the prehistoric occupations have not been determined.

The site was tested by excavating six $1-\mathrm{m}^{2}$ units and three half-meter units within and just outside the pipeline easement. Excavations began by following natural levels of about $25 \mathrm{~cm}$, then to $10-\mathrm{cm}$ arbitrary levels in adjacent units for finer control. Because of previous surface alterations, surface materials were scarce and were not a reliable indicator of subsurface deposits. Also, it appears that previous surface alterations and perhaps some erosion have removed much of the upper cultural strata at the lower elevations of the site.

When the levels containing burned limestone fragments are compared using the elevation above mean sea level instead of depth below the modern surface (this elevation is $558.96 \mathrm{feet}$ ), then all levels align themselves to show a consistency in percentage of debitage at each level (Fig. 3). The greatest amount of debitage per $10-\mathrm{cm}$ increment is found within the $10-\mathrm{cm}$ increment containing burned limestone. The amount of debitage per level decreases with lessening elevation until the level containing the possible hearth feature is reached ( 557.71 feet above msl). The debitage at this level is a higher percentage of total debitage than either the level above it or the level below it. Therefore at least two distinct occupational levels are postulated.

Because debitage is found at all levels (to an adjusted depth of $1.2 \mathrm{~m}$ ), it is possible that this site was occupied regularly over a great deal of time. With the total amount of debitage recovered (about 1100 flakes), in addition to 12 biface fragments, the odds of finding diagnostic artifacts should be high. Although cultural material was diminishing at the $1-\mathrm{m}$ depth, where the clayey soil became very hard packed and difficult to work in a small space, the excavations were not carried deeper to verify indisputable sterile underlay. The decision was made to use the time available for a broader examination of the site instead of a deeper excavation.

The results of the testing indicate that $41 \mathrm{BX} 785$ occupies an area of more than $200 \mathrm{~m}^{2}$ within the 50-foot-wide easement. The easement extends east-west and parallel with Salado Creek and Villa Vista Drive. The tests have shown that the site occupies locally elevated topography within the easement (Fig. 2). Tests to the east and west within the easement indicate greatly diminished subsurface cultural materials represented by only a small quantity of scattered chert flakes to delineate the site limits. To the north, outside and downslope from the easement, the recovered materials were somewhat less, but evidently the site extends in that direction. 
The higher elevation to the south, between the easement and Villa Vista Drive was not tested, but the site may also extend in that direction. However, development in this area may have impacted the site.

In summary, we can state that $41 \mathrm{BX} 785$ is a prehistoric site of undetermined date and of uncertain total area. It appears to have been a campsite and workshop as indicated by remnant hearths, mussel shell, chert biface fragments, and lots of chert debitage, evidently the result of making and refurbishing stone implements. Some of the chert flakes were small tools as evidenced by retouch flaking or use-wear. Although several chert biface (small) fragments were recovered, none were diagnostic. The site had at least two occupation episodes as seen in the two distinct stratigraphic levels, each with a living floor area as defined by burned and fractured hearthstone, ashy lenses, freshwater mussel shell fragments, land snail (Rabdotus) shells, and relative densities of stone chipping debris.

Unfortunately, the major problem at $41 \mathrm{BX} 785$ is the lack of diagnostic artifacts and a definitive chronology. The site was a habitation workshop where stone implements were evidently made and refurbished as evidenced by the relatively dense deposits of debitage representing primary, secondary, interior, and thinning flakes. However, it is currently unknown what types and forms of tools or hunting points were made and used. Without this information it is difficult to speculate in a useful way on such things as hunting and gathering strategy and methods of food preparation.

Site 41 BX 785 has intact buried, stratified deposits that have provided useful information through assessment testing. We believe that through further planned mitigative excavations the site is likely to provide important information on the prehistory of southeastern Bexar County. Because the site lies within the pipeline easement it will be impacted by trenching activities. Relatively little information has been assembled from preliminary studies of other prehistoric sites in the general area, and possibly sites have been destroyed in the past through creek channeling and other developments in the project area. This site has the potential to provide a broader data base from which to form meaningful interpretations. Therefore, we consider $41 \mathrm{BX} 785$ to be potentially eligible for designation as a State Archeological Landmark and for nomination to the National Register of Historic Places.

We recommend that further investigations at 41 BX 785 should include, at a minimum, the opening of at least a $4-\mathrm{m}^{2}$ block excavation centered within the easement in the area where testing has indicated intact buried deposits. Additional smaller tests might also be employed, particularly to the north and south of the easement where an extension of the site is suspected. The block excavation will provide for a broader horizontal investigation of the stratified deposits (and hopefully provide datable diagnostics and other cultural materials) and will allow investigation to a depth sufficient to determine if there may be deeper buried deposits. We also recommend that a backhoe be employed to selectively trench in or adjacent to the site to document the terrace profile and to record any deeper deposits that might be impacted by the planned pipe trench. We consider this to be a unique opportunity to document an intact stratified site on the lower Salado Creek.

\section{REFERENCES CITED}

Black, S. L. and A. J. McGraw

1985 The Panther Springs Creek Site: Cultural Change and Continuity Within the Upper Salado Creek Watershed, South-Central Texas. Center for Archaeological Research, The University of Texas at San Antonio, Archaeological Survey Report 100.

Brown, D., P. Lukowski, T. R. Hester, and J. D. Eaton 1977 Archaeological Assessment of Two Sites in the Vicinity of Floodwater Retarding Structure No. 11, Salado Creek Watershed, Bexar County, Texas. Center for Archaeological Research, The University of Texas at San Antonio, Archaeological Survey Report 35.

Burkett, R. W. and J. A. Huebner

1989 An Archaeological Assessment (Phase I) of the West Salado Creek Outfall Project, Southeastern Bexar County, Texas. Center for Archaeological Research, The University of Texas at San Antonio, Archaeological Survey Report 181.

Fox, A. A.

1977 An Archaeological Assessment of the San Antonio 201 Wastewater Treatment Project. Center for Archaeological Research, The University of Texas at San Antonio, Archaeological Survey Report 41. 
Fox, A. A., A. J. McGraw, and F. Valdez, Jr.

1978 Archaeological Survey and Testing of Pipelines and Confluence Site, San Antonio 201 Wastewater Treatment Project. Center for Archaeological Research, The University of Texas at San Antonio, Archaeological Survey Report 66.

Gibson, E. C., C. J. Jones, and D. A. Knepper

1982 Archaeological Investigations of Areas Slated for Expansion at Fort Sam Houston National Cemetery, San Antonio, Texas. Center for Archaeological Research, The University of Texas at San Antonio, Archaeological Survey Report 119.

Hester, T. R.

1974 Archaeological Survey of Areas Proposed for Modification in the Salado Creek Watershed, Bexar County, Texas. Centerfor Archaeological Research, The University of Texas at San Antonio, Archaeological Survey Report 3.

1980 Digging Into South Texas Prehistory. Corona Publishing Company, San Antonio, Texas.

McGraw, A. J. and F. Valdez, Jr.

1978 Investigations of Prehistoric Rockshelter and Terrace Sites Along Portions of the Salado Creek Drainage, Northern Bexar County, Texas. Center for Archaeological Research, The University of Texas at San Antonio, Archaeological Survey Report 55.

Prewitt, E. R.

1981 Cultural Chronology in Central Texas. Bulletin of the Texas Archeological Society 52:65-89.

Snavely, R., M. Greco, and A. A. Fox

1984 Archaeological Assessments for the San Antonio 201 Wastewater Treatment Project: Survey of Five Pipeline Routes and Testing at Site $41 \mathrm{BX}$ 333. Center for Archaeological Research, The University of Texas at San Antonio, Archaeological Survey Report 131.
Taylor, F. B., R. B. Hailey, and D. L. Richmond

1966 Soil Survey of Bexar County, Texas. United States Department of Agriculture, Soil Conservation Service, in cooperation with the Texas Agricultural Experiment Station, Series 1962(12).

Turner, E. S. and T. R. Hester

1985 A Field Guide to Stone Artifacts of Texas Indians. Texas Monthly Press, Austin. 




